\title{
ANSELM'S METAPHYSICS OF NONBEING
}

\section{DALE JACQUETTE}

University of Bern

\begin{abstract}
In his eleventh century dialogue De Casu Diaboli, Anselm seeks to avoid the problem of evil for theodicy and explain the fall of Satan as attributable to Satan's own self-creating wrongful will. It is something, as such, for which God as Satan's divine Creator cannot be held causally or morally responsible. The distinctions on which Anselm relies presuppose an interesting metaphysics of nonbeing, and of the nonbeing of evil in particular as a privation of good, worthy of critical philosophical investigation in its own right. Anselm's concept of nonbeing does not resolve the philosophical problem of evil implied by Satan's fall from grace, but is shown perhaps more unexpectedly to enable Anselm's proof for the inconceivable nonexistence of God as the greatest conceivable intended object of thought to avoid Kant's Critique of Pure Reason objection to the general category of 'ontological' arguments.
\end{abstract}

\section{ANSELM'S CONCEPT OF EVIL}

Anselm of Canterbury, in his dialogue De Casu Diaboli ('On the Devil's Fall'), maintains that evil is only a privation of good, and that God as the source exclusively of being or that which exists cannot be responsible in any sense for privations. Hence, also, God cannot be responsible for the existence of evil. The concept of privation or the nonbeing or nonexistence of things is thereby elevated to a place of explanatory importance in Anselm's metaphysics, as a consequence of his theological examination of the problem of evil and the fall of Satan. ${ }^{1}$

Anselm's understanding of nonbeing is worth examining in detail, not only as it appears in his Three Philosophical Dialogues, but also in

\footnotetext{
${ }^{1}$ References to and translations of De Casu Diaboli are from the Hopkins and Richardson edition of Anselm (1967).
} 
the Proslogion. Anselm's famous 'ontological' proof for the existence of God, as Immanuel Kant later styled it, can best be explained against the background of his concept of privation and nonbeing, and the question of whether that than which nothing greater is conceivable can finally partake of nonbeing.

Kant's objection to Anselm's argument in his (1781/1787) Critique of Pure Reason similarly depends on the assumption that an intended object than which nothing greater is conceivable establishes at most only the existence of a certain concept of God. Kant denies Anselm's attempt to prove that God is an actually existent entity, notwithstanding our possessing an idea of something whose concept is supposed to imply its existence. Kant's criticism presupposes the possibility of there being genuine existent concepts to which nothing existent corresponds outside the mind. If Anselm's metaphysics of nonbeing is correctly interpreted, then the conventional Kantian complaint fails to demonstrate a deductive invalidity in Anselm's reasoning. ${ }^{2}$

\section{ALL AND ONLY BEING OF THE GOOD FROM GOD}

Anselm does not set out in De Casu Diaboli with the explicit purpose of articulating a metaphysics of nonbeing. Anselm addresses problems in philosophical theology by arguing that God confers all and only good things on human beings and righteous and wayward angels alike. The evil we suffer, according to Anselm, following a precept of Augustine, is never anything positive, and hence ultimately nothing whatsoever. ${ }^{3}$

In the process of demonstrating that God is not the source of evil in the world, Anselm is driven by default toward the basic principles of a metaphysics of nonbeing. It is the direction his thoughts most naturally incline him to develop, given his interest in answering the problem of evil as he does. The fact, moreover, that Anselm's metaphysics of nonbeing arises out of necessity actually strengthens his position and sustains its independent interest, despite appearing in the service of a cluster of religious and metaphysical assumptions that sceptics need not accept.

What is remarkable about Anselm's work in philosophy is his astute drawing of important distinctions in observing subtle linguistic nuances of more general philosophical application. Despite his medieval frame

\footnotetext{
${ }^{2}$ See below note 23 .

${ }^{3}$ Augustine (2010), vol. 22. De Natura Boni Contra Manichaeos [c. 405].
} 
of reference, Anselm's thought in this connection looks remarkably modern and even contemporary, when he is read purely in appreciation of the logical structure of his philosophical inferences. The dialogues represent an exercise of considerable philosophical ingenuity within the constraints of holy writ in support of Christian dogma.

Nowhere are these features of Anselm's philosophical abilities more conspicuously in evidence than in De Casu Diaboli, written by Anselm sometime between 1085-1090. Jasper Hopkins and Herbert Richardson, in their edition and English translation of Anselm's dialogues under the title, Truth, Freedom, and Evil: Three Philosophical Dialogues, appear to agree with this assessment when they write, in their insightful 'Editors' Introduction': 'Of the three dialogues, De Casu Diaboli is the most lucid, its argument the most consistent, its movement the most organized.' We turn to this work for insight into Anselm's implicit metaphysics of nonbeing as a key to his efforts to solve the problem of evil and as reinforcing his conceivability argument for the existence of God.

\section{DIMENSIONS OF ANSELM'S PHILOSOPHICAL DIALOGUE}

Anselm's De Casu Diaboli, like his dialogues De Veritate ('On Truth') and De Libertate Arbitrii ('On Freedom of Choice'), takes place between a Teacher and a Student. The dynamic is significant, because the dialectic is not presented as a discussion among equals, but as reflecting the Teacher's attitude of superior wisdom in relation to the Student. The philosophical conversations in Anselm are different in this respect, despite the obvious hero of the works, from Plato's dialogues, George Berkeley's (1713) Three Dialogues Between Hylas and Philonous, and even, where the principal triumphant voice is more difficult to identify, David Hume's (1779) Dialogues Concerning Natural Religion. The master-disciple gradient in philosophical exchange in Anselm's dialogues is not unique, but found, for example, among other especially medieval sources, notably in Boethius's (c. 524) Consolatio Philosophiae, where lady Philosophy does not debate with the prisoner, but imparts her comforting wisdom ex cathedra. The difference might point toward a more general trend in medieval religious philosophy, wherein questions are encouraged and doubts entertained, but are always answered from a higher standpoint of epistemic and moral authority.

\footnotetext{
${ }^{4}$ Hopkins and Richardson, 'Editors' Introduction', in Anselm (1967), p. 44.
} 
Again, like Anselm's other dialogues, De Casu Diaboli begins with a quotation from scripture. Anselm, in this case, cites 1 Corinthians 4:7:

That it is even said to the angels, 'What do you have that you have not received?' And from God comes nothing except goodness and being; and every good is a being, and every being a good. ${ }^{5}$

Anselm's choice of opening Biblical verse is noteworthy in two ways. First, it is interesting to see that negation, nothing, and nonbeing are emphasized in the thematic citation before the dialogue even gets under way. The question posed is whether the angels have anything that they have not received, and we are told that nothing comes from God except goodness identified with being. Second, it is important to notice that Anselm's solution to the problem of evil is already prefigured in the passage from 1 Corinthians. The dialogue serves ultimately as a commentary on the gospel of Paul, and only needs to be spelled out more completely in order to exhibit its full implications for the problem of evil. If God creates only goodness identified with being, and evil as lack or deprivation is nothing or nonbeing, then evil, nugatory at best or at worst, cannot come from God.

Admittedly, this reply does not yet answer the second-tier problem of why God appears not to prevent evil from being visited upon the world from other sources. To permit evil to occur, or to stand by without preventing its occurrence, even without sanction, when it is putatively within God's power to do so, leaves more virulent formulations of the standard problem of evil untouched. This is precisely the version of the objection discussed at length by the early Church father, Lucius Caecilius Firmianus Lactantius, in The Wrath of God (De Ira Dei, c. 311-312), a source with which Anselm could have been familiar, since it was written, even if not widely circulated, already in the fourth century. ${ }^{6}$

${ }^{5}$ Anselm (1967), p. 147.

${ }^{6}$ Voltaire in his Dictionnaire philosophique cites a classic form of the problem of evil directed against the existence of God, dialectically considered by Lucius Caecilius Firmianus Lactantius in his (318) manuscript, De Ira Dei (The Wrath of God), available to Voltaire in a number of editions, beginning with a Swedish collection of the Lactantius Opera omnia in 1465. Voltaire (1962) writes: '... I must quote Lactantius, Church Father, who in chapter 13 of The Wrath of God has Epicurus say this: "Either God wishes to expunge the evil from this world and cannot; or he can and does not wish to; or he neither can nor wishes to; or finally he wishes to and can. If he wishes to and cannot, that is impotence, which is contrary to the nature of God; if he can and does not wish to, that is wickedness, and that is no less contrary to his nature; if he neither wishes to nor 
The argument itself, in a variety of forms, was in any case common coin in philosophical theology by Anselm's time. Versions of the argument are taken up later, among other sceptical writings, most conspicuously by Voltaire's Dictionnaire philosophique and Hume's Dialogues, emphasizing the conflict between God's supposed omniscience, omnipotence, and perfect benevolence, with the existence in the world of natural evil (Hume) or physical evil (mal physique, in the words of Voltaire). ${ }^{7}$ In reply to Anselm and Paul, we might ask if there is evil that does not derive from God, whether God does not know about it, is unable to prevent it, or that God knows about and could forestall, but chooses not to prevent. If the answer to any of these questions is yes, and if only a negative answer mitigates the logical conflict that otherwise results from the joint affirmation of these propositions, then the existence and presumptive perfect nature of God remains logically incompatible with the existence of natural evil, even if God is not its source.

This pedestrian objection is anticipated early in Anselm's dialogue. Already in Chapter I, the Teacher explains to the Student: 'For since there are only two states of being, one which has created and the other which has been created, it is evident that nothing can exist, except the Creator and his creations.' ${ }^{8}$ If this proposition is true, then it follows that, despite appearances, evil as literally nothing does not exist. There exists, in that event, only the Creator and whatever the Creator creates. Since evil is always the privation of good, and since privation as the absence or lack of something is not something created, evil simply has no being. Logically, then, evil does not and cannot exist, as long as the world is something that has been created. If, finally, there is no such thing as evil, then there is no basis in evil for challenging the existence or attributes of God as divine Creator.

can, that is wickedness and impotence at the same time; if he wishes to and can (which is the only one among these choices appropriate to God), where does the evil in this world come from?"' (p. 117) Voltaire seems to relish quoting an august theologian on the problem of evil, particularly as Lactantius's solution is so unsatisfying, maintaining that 'God wishes evil, but has given us the wisdom with which to choose the good' (pp. 117-118). Voltaire comments not only on Lactantius's confused logic and concept of God as something less than perfectly benevolent, but also on the unintentional humour in delegating human wisdom to overcome evil.

7 See Hume (1947), Part 11, on the distinction between moral and natural evil. Voltaire in (1993) distinguishes between physical and moral evil (p. 96): 'du mal moral et du mal physique'.

${ }^{8}$ Anselm (1967), p. 147. 
The stubborn problem that this kind of solution does not immediately resolve is accounting for the appearance of evil that seems so prevalent a feature of the real world, despite all rational inference to the contrary. Nor can it suffice blithely to invoke the appearance-reality distinction here, despite acknowledging the chain of philosophical debt that extends historically backward from Anselm to Augustine, from Augustine to Plato, and from Plato to the pre-Socratic Parmenides. These doctrinal lineages do not absolve Anselm of the need to provide a better answer to the remaining problem of explaining the manifest appearance of evil merely by arguing that evil cannot be real, cannot exist, and that therefore whatever we consider to be evil must somehow be apparent rather than existent. The pain and sorrow and other natural evils that seem to prevail in this vale of tears, the sufferings and woes as they are experienced at least by the sufferer, appear to be every bit as real as the good and harmonious things that we also experience in God's world. They are moments of appearance in the world of or as appearance, and the problem of evil is fully recoverable under the appearance-reality distinction as the challenge of understanding how such imperfect appearances can occur so conspicuously in a world that is supposed to be the production of a perfect Creator.

\section{SATAN'S FALL FROM GRACE}

One of the dialogue's main purposes, as the title indicates, is to account for the fall of Satan, and to do so in such a way that God is left blameless in whatever Satan does to bring about his own descent from grace. There is a risk of God's being implicated in Satan's plunge, if God is truthfully credited with Satan's wrongdoing, interpreted by the Teacher and Student in Anselm's dialogue as a lack of perseverance in the ability to exercise the purely good will that Satan originally receives from God.'

Satan, as chief among the evil angels, would appear to lack perseverance in the good, because, as the Student in Anselm's dialogue expresses it, God did not give Satan a properly-directed will. If Satan had

${ }^{9}$ A tradition in popular religion that has sometimes been adapted for philosophical purposes tries to relate natural evil to the moral evil of distant ancestors (see inter alia Plantinga (1974)). The proposal is impeded when we reflect that moral evil is the result of natural dispositions in the exercise of decision and will for which the Creator of the universe is also presumably in some sense causally and morally responsible. Why were human beings so created as to sometimes choose moral evil? 
only possessed adequate perseverance, a good thing, which God might have bestowed upon instead of withholding from Satan, then Satan would never have fallen. The Teacher immediately and quite reasonably replies that not receiving something is not always the result of its not being given. God gives Satan both the ability and the will to receive God's further gift of perseverance, but Satan resists God's offering, and does not persevere in willing to receive God's supplementary sustaining gifts. Satan in exercising free choice does not will the necessary perseverance God offers to resist entertaining a forbidden desire. God did not succeed in giving Satan a persevering will only because Satan refused and would not receive it from God. As Anselm's Teacher explains to the Student: 'When the will deserted [the] uprightness, it lost something noble, and it received nothing in place of it except the privation of it. And this privation, which we call injustice, has no being. ${ }^{10}$ Even so, we are naturally left to wonder how God, as a perfect being, Satan's Creator, on the assumption that Satan exists, could try and fail to endow Satan with the perseverance Satan would have needed to persist in resisting his wilful fall.

\section{EVIL AS NOTHING AND THE METAPHYSICS OF NONBEING}

The discussion in Anselm's dialogue now turns philosophically to the problem of what is meant by the term 'nothing'. It is supposed to signify literally nothing whatever, or nonbeing; yet it accepts qualifications in predicate attributions. Nothing seems paradoxically to be something after all, a subject capable of having properties. We can meaningfully think and say things about nothing, suggesting that it does after all have at least some type of signification. Anselm's Student accordingly asks:

... if people are right in saying that what is called nothing really is nothing and never is something, then what else could follow except that the word 'nothing' simply means nothing, i.e., it does not signify anything at all. So we come to this problem, how can the word 'nothing' signify not nothing, but something; and how can it signify not something, but nothing. ${ }^{11}$

The problem in a sense is the same as that addressed by Socrates in Plato's dialogues the Parmenides and Sophist, where Plato concludes that nonbeing in some sense 'is' in order to have the property of nonbeing.

\footnotetext{
${ }^{10}$ Anselm (1967), p. 162.

${ }^{11}$ Ibid., p. 164.
} 
Anselm's Teacher in the dialogue responds rather differently, introducing an innovation that does not seem to have occurred to Plato, distinguishing between two different senses of 'signifying nothing'.

Teacher disambiguates one meaning of the phrase as implying something removed, leaving literally nothing behind, but still referring to what had existed; and another as implying something determined, ascribing a definite positive property to a thing, from which signifying nothing seems altogether precluded. In one sense of 'signify', 'nothing' signifies nothing; while in another, attenuated, sense, 'nothing' can be said to signify the sorts of things of which the Student's objection takes notice. The Teacher adds: 'So this word "not-something" ... in some sense signifies something [that which is missing or has been removed]. For it signifies by removing and it does not signify by determining.' ${ }^{\text {12 }}$ Teacher now continues:

For this same reason, the name 'nothing', which negates whatever is something, signifies something rather than nothing by its removing, and it signifies nothing rather than something by its determining. For it is not necessary that nothing be something simply because its name somehow signifies something; rather, nothing must be nothing, because the word 'nothing' signifies something only in the sense we've mentioned. So in this way, it is not repugnant to think that evil is nothing or that the name 'evil' is significative; for this name is determinative of no thing when it signifies the negation of something. ${ }^{13}$

Anselm's answer to the problem of making sense of the phrase that 'nothing exists' or that 'something does not exist' is rather different than Plato's. Anselm cuts the Gordian knot by insisting upon a distinction according to which the word 'nothing' signifies in a peculiar sense only that which we say does not exist, leaving 'signifies' in its ordinary meaning for ordinary names other than 'nothing', that genuinely refer to objects conceivably standing as the bearers of properties. Teacher further illustrates the point by invoking a comparison between the terms 'nothing' and 'evil' with 'blindness' as a lack, signifying nothing, the not having of something (sight) or not-something, its predicative complement:

Therefore, in this way, 'evil' and 'nothing' signify something; and what they signify is something not according to fact, but according to the form of speaking. For 'nothing' only signifies not-something, or the absence of

\footnotetext{
${ }^{12}$ Anselm's original Latin term is constitutio.

${ }^{13}$ Anselm (1967), p. 166.
} 
whatever is something. And evil is nothing else except not-good, or the absence of good where good should be, or where it is useful for it to be. But what is nothing other than the absence of that which is something is certainly not something. So evil truly is nothing, and nothing is not. ${ }^{14}$

In time-honoured polemical fashion, Anselm's Teacher further casts aspersions on colloquial terminological misapplications of a vocabulary about God's creation of a world in which natural evil occurs. 'For we say many things improperly in our ordinary way of speaking', Anselm's Teacher remarks. 'But when we wish to come to the heart of a matter, it is necessary to analyze, as far as the subject matter allows, the improper usage which is troubling us. ${ }^{15}$ Such abuses of language include the kinds of things we sometimes say that lead us into philosophical conundrums about God's existence and nature, as reflected specifically in the problem of evil. 'For just as we say that God leads someone into temptation,' Teacher continues, 'when He doesn't free him from it, so we say He gives an evil will by not prohibiting it when He can - especially since the ability to will anything at all comes only from God. ${ }^{16}$ We may question the extent to which Anselm's distinction accords with ordinary usage beyond the selected examples he considers. Contrary to Anselm's implication, to say that an all-purpose cardboard box purchased new at a store to house any number of appropriate size objects contains nothing at a certain time does not necessarily signify any, let alone all, of the things that might be placed in it, nor the absence or privation of any particular thing.

Ultimately, Anselm's imaginary Teacher argues that Satan falls by willing divine happiness. Satan wills to be like God in a free act of unjust willing for a kind of happiness that can only properly belong to God. Satan wills something other than he is entitled to will, and thereby brings about his own downfall, leading a train of other fallen angels guilty of the same offence away from eternal bliss. All this is pure speculation on Anselm's part, needless to say, projecting a history of events in heaven that preserves logical consistency with God's existence and perfection. The explanation, nevertheless, is driven by logical argument, without further appeal to authority beyond a scattering of scriptural verses taken as touchstones for discussion. Satan must have fallen in this way, Anselm concludes, since reason, as the dialogue is supposed to demonstrate,

\footnotetext{
${ }^{14}$ Ibid.

${ }^{15}$ Ibid., p. 176.

${ }^{16}$ Ibid., p. 183.
} 
supports no other possible inference. The metaphysics of being and nonbeing, something and nothing, now come under scrutiny once again in direct application to the problem of understanding Satan's fall, and the question as to whether God had any moral responsibility in the event. Teacher maintains:

So when Satan turned his will to what he should not, both that willing and that turning were something; and yet he had this something only from God and by the will of God, since he could neither move his will nor will anything except through the permission of the One who makes all substantial and accidental and universal and individual natures. Insofar as Satan's will and its turning, or movement, are something, they are good and they are from God. But insofar as his will lacks the justice that it shouldn't lack, it is something evil - though not purely an evil; and whatever is evil is not from God but from willing, or from the moving of the will. ${ }^{17}$

Student is convinced, and dutifully replies:

I don't have anything to argue against this. For indeed, I am unable to deny actions in general to be something, and I do not wish to deny that whatever has being comes from God. Nor does your argument in any way accuse God or excuse Satan; rather, it completely excuses God and accuses Satan. ${ }^{18}$

That should be the end of their discussion, although there remains one further topic for the interlocutors to explore.

\section{WHY THEN IS EVIL FEARED?}

As an unexpected reprise, Student, who has admitted to having had his difficulties satisfactorily addressed, still has a few unanswered doubts. He now rejoins: 'Although you have answered all my questions up to now' Student proceeds, 'yet I await your explaining what it is that we dread when we hear the name "evil", and what causes things like robbery and lust, which injustice and evil seem to do, if evil is nothing?' 19

A reasonable question. If evil is literally nothing, then why do we take up attitudes toward it as though it were something real? Why do we consider it something to be avoided, to prepare against, or in many

\footnotetext{
${ }^{17}$ Ibid.

${ }^{18}$ Ibid., p. 184.

${ }^{19}$ Ibid., p. 193.
} 
instances to be suffered, if we can endure, as the plain facts testify? Teacher's explanation is incomplete, Student respectfully implies, without a good answer to this problem. Teacher replies that we sometimes falsely though understandably attitudinize evil by misidentifying the absence of something important to our welfare as though it were something real:

But we are to think that if justice were in the will and sight in the eyes, then neither the robbery nor the fall into the pit would have taken place. It is as if we were to say, 'The absence of a rudder drives the ship onto the rocks', or 'The absence of reins causes the horse to run wild'. In these statements we mean only that if a rudder or reins were present, then the winds would not drive the ship onto the rocks nor would the horse run wild. ${ }^{20}$

We learn that for Anselm, a cause of something must always be something positive, an existent thing or event, and not a mere lack or absence of something that permits other prevalent existent causes to bring about primarily unwanted occurrences, as incidents of natural evil. We cannot correctly say with Anselm, although we do frequently speak this way, that a horse stumbles because it lacks a shoe, or that it loses its shoe because the shoe lacks a nail. ${ }^{21}$ Such a constraint is hard to reconcile with a more widespread appeal to true counterfactuals of just this kind as proof of causation. We generally expect that a causal connection obtains between two temporally distinct events E1 and later E2 when it is known on independent grounds that if E1 had not occurred, then E2 would not have occurred. Anselm seems to want to exclude such reasoning on the basis of several counterexamples, which he presumably considers representative of an unlimited field.

Looking into Anselm's argument, we can only evaluate his conclusions on the strength of the argument he presents. This methodological guideline follows upon a truism, since anything else would not concern but imaginatively go beyond Anselm's documented inferences. Unfortunately, Anselm's purported counterexamples are not very convincing as true counterfactuals that fail to support causal connections. The presence of a rudder by itself would not prevent a ship from being driven up on the rocks, say, in a tsunami. Although with reins we might better control a horse, it is not plausible or even very probable that the mere presence of reins would prevent horses from being driven wild by other causes.

\footnotetext{
${ }^{20}$ Ibid., pp. 193-194.

${ }^{21}$ I develop a semantics and discuss an accompanying ontology in which lacks and absences can reasonably be construed as causes in Jacquette (2010).
} 
Anselm needs to show that there are true counterfactuals that do not imply a corresponding causal connection. However, in both of his supposed counterexamples, we do not have true counterfactuals to begin with, and it comes as no surprise that the events he describes are not judged to be causally related.

Finally, the explanation of how Satan as the leading evil angel first willed unjustly reveals something interesting about Anselm's concept of will and its causation. Student first asks: 'Why, then, did he [Satan] will?' To which Teacher answers: 'Only because he willed. For there was no other cause by which his will was in any way driven or drawn; but his will was both its own efficient cause and its own effect - if such a thing can be said!'22 Will is to blame for Satan's fall, or rather the fatal content and intentionality of a particular moment in the exercise of will. We might accordingly conclude that when they are able to do so, spirits command nothing more powerful than their own sovereign wills. Anselm's Teacher concludes that Satan wrongfully wills to have a wrongful will. The event does not take place through Satan's having been created with a corrupt will, for that would indict God's blame in Satan's fall. Satan's simultaneous wrongful willing of a wrongful will is entirely self-creating, and hence something for which only Satan is causally and morally responsible.

If such a thing can be said, is exactly what alert philosophical critics should question. We must ask Anselm's Teacher how a perfect God could have created a spirit like Satan with the foreknowable propensity to selfcreate what in God's own righteous judgment is destined to be deemed a wrongful will. We are driven again to conclude that will is perhaps the most powerful and potentially dangerous force in the universe. Without trying to make better sense of Satan's wilful self-creating act of moral evil, and on Anselm's closing ambivalent note, we turn next to an unexpected application of Anselm's discussion of being and nothingness.

\section{CATEGORIES OF BEING AND THE 'ONTOLOGICAL’ ARGUMENT}

Anselm's argument for the existence of God, giving faith independent rational support, is too well known to require detailed exposition. Anselm presents the so-called second ontological proof in Proslogion III:

For there can be thought to exist something whose non-existence is inconceivable; and this thing is greater than anything whose non-existence

${ }^{22}$ Anselm (1967), p. 195. 
is conceivable. Therefore, if that than which a greater cannot be thought could be thought not to exist, then that than which a greater cannot be thought would not be that than which a greater cannot be thought - a contradiction. Hence, something than which a greater cannot be thought exists so truly that it cannot even be thought not to exist. And You are this being, O Lord our God. Therefore, Lord my God, You exist so truly that You cannot even be thought not to exist. ${ }^{23}$

The inference maintains that God, defined as that than which none greater is conceivable, must exist. Otherwise, the argument implies, it would be possible to conceive of a being greater than God; which, namely, would be a being with all of God's properties that additionally also exists. An existent God is something at least conceivably greater than a nonexistent God.

Kant's objection to Anselm's argument is also well known, despite being frequently misinterpreted. The idea is that existence cannot be included among an object's object-individuating, identity-determining, or identity-constituting constitutive properties, as Anselm's proof is sometimes alleged to require. For otherwise we could not intelligibly affirm or deny that the very same identical object exists. Kant illustrates the limitation with the example of 100 gold Thalers, referring to individuating, identity-determining or identity-constituting constitutive properties excluding their existence or nonexistence as predicates. ${ }^{24}$ Kant's criticism crucially depends on the assumption that the existence and nonexistence of God marks a dichotomy of possible ontic states that are just like or precisely parallel to those of any other object. What we discover in Anselm's discussion of nonbeing in De Casu Diaboli effectively blunts the force of Kant's objection, whether or not Anselm's Proslogion inference is rightly classified as an 'ontological' argument in the sense presupposed by Kant's criticism.

The question is whether, for Anselm, trying to conceive of God as not existing, having all of God's characteristic properties plus nonbeing, is properly described as an effort to think of nonbeing as a predicate

${ }^{23}$ Anselm (1974), I, p. 94. Anselm writes (1945-1951), I, pp. 102-103: 'Nam potest cogitari esse aliquid, quod non possit cogitari non esse; quod maius est quam quod non esse cogitari potest. Quare si id quo maius nequit cogitari, potest cogitari non esse: id ipsum quo maius cogitari nequit, non est id quo maius cogitari nequit; quod convenire non potest. Sic ergo vere est aliquid quo maius cogitari non potest, ut nec cogitari possit non esse. Et hoc es tu, domine deus noster. Sic ergo vere es, domine deus meus, ut nec cogitari possis non esse.'

${ }^{24}$ Kant (1965), 'Ideal der reinen Vernunft', A599/B627-A600/B628. 
in Kant's sense, which is to say, as a constitutive, object-individuating or identity-determining property. If Anselm does not propose this, then, however appropriately Kant's objection might apply to similar formulations of ontological arguments for the existence of God, such as Leibniz's in his (1765) New Essays on Human Understanding, or Descartes' in his (1641) Meditations on First Philosophy V, it can have no effect on Anselm's Proslogion statement of a significantly different form of the argument. ${ }^{25}$ Anselm is reasonably understood as not regarding either being or nonbeing as object-individuating or identity-determining properties in the sense of Kant's predicates. There is no justification for such an attribution to Anselm that would inexplicably contradict his explicit contrary commitments in De Casu Diaboli. There, as now seen, Anselm emphatically declares that nonbeing is nothing whatsoever, and hence not an identity-determining or individuating property. Anselm says unequivocally in discussing the nonbeing of evil that it is neither Creator nor any part of creation, and hence not a part of the universe at any time or place. It is also worth recalling that Kant, in refuting a generic form of the ontological argument in the Critique, nowhere mentions Anselm by name, despite referring explicitly to both Descartes and Leibniz as particular exponents of the ontological argument. We can only speculate as to whether Kant means his objections to include the significantly different inferential form of Anselm's reasoning. It is clear nonetheless that Kant's objections apply more cogently if at all, not to Anselm's argument, but to Descartes' much later version that actually fits Kant's description, and to Leibniz's amendments of Descartes' ontological proof.

Although Anselm's inference is frequently but inaccurately included in the category of 'ontological arguments', as Kant later styles them, Anselm appears to be reasoning rather differently. Sufficient attention to the details and giving proper emphasis to and inquiring into the meaning of the differences between Anselm's and Descartes-Leibniz, reveals that Kant's sense of the concept includes all and only those inferences to establish the existence of God that depend on the proposition that existence is somehow included analytically in the concept of a perfect being. Anselm may also believe this, but his argument does not require the assumption that a perfect being must also possess the perfection of

${ }^{25}$ See inter alia Malcolm (1960); Shaffer (1962); Engel (1963); Plantinga (1966); Schufreider (1978); Brecher (1985); Bencivenga (1993). 
existing. He maintains instead that God exists, because by 'God' we mean to designate the greatest thing we are capable of conceiving, and because we cannot conceive of the greatest conceivable thing as not existing.

Whatever the merits of the inference, Anselm's argument does not explicitly assume that the property of existing belongs to the nature or essence of God, even as that than which nothing greater is conceivable. The argument on this reconstruction does not really say anything about God, as opposed to the word 'God', until the very end, and does not mention God's nature or essence, or the properties attributable to God, but only to what we can and cannot conceive of as implied by the concept of being the greatest. What is great and what is not so great is not investigated, although we may expect to find such traditional monotheistic divine greatness attributes as omnipotence, omnipresence, omniscience, and perfect benevolence. Anselm does not mention these or any other properties of the greatest conceivable being in the context of the argument, and he seems understandably unwilling within or as part of an inference to ascribe any properties to an object whose existence the argument itself is first supposed to demonstrate. Anselm, for the same reason, unlike Descartes and Leibniz, cannot be expected to maintain that existence as a constitutive identity-determining property is a perfection analytically included among all perfections in the nature or essence of a perfect being.

We may still wonder why Anselm would regard it as inconceivable for the greatest conceivable being not to exist, unless like Descartes and Leibniz he includes or tries anyway to include existence analytically among the properties and hence part of the nature or essence of a greatest conceivable being. The fact that Anselm might or even would probably also have agreed with these propositions should not be confused with what he explicitly includes in or excludes from his attempted proof for the existence of God, or even with what he would need to include in order to carry his inference. The weight of evidence is entirely on what can be deduced from the conceivability of the greatest conceivable being as of that than which none greater is conceivable. Anselm believes that the greatest conceivable being must actually exist, because to suppose otherwise leaves us with the possibility of conceiving something yet greater. Why, however, would such a conceivable being be greater by virtue of existing rather than not existing, if to exist were not a property contributing at least to an otherwise perfect conceivable being's greatness? Anselm can answer such questions easily by maintaining that in his argument 
existence rather than nonexistence, being rather than nonbeing, does not need to contribute to a conceivable being's greatness, but only to whether or not when we try to conceive of such a thing we succeed in conceiving of what would actually be the greatest conceivable being. If we are conceiving only of something great in many ways, but that does not actually exist, then we are not yet conceiving of the greatest conceivable being or of a being that is as great as it would be possible for it to be.

Does this difference suffice to remove Anselm's argument from Kant's criticism of 'ontological' proofs like Descartes' and Leibniz's? Why does Anselm regard it as inconceivable for the greatest conceivable being not to exist, unless, like Descartes and Leibniz, he includes or tries anyway to include existence analytically among the properties and hence as part of the nature or essence of a greatest conceivable being? What else could set the limits on the conceivability of the greatest conceivable being, if not the properties essential to the greatest conceivable being's constitutive identity conditions?

Anselm believes that the greatest conceivable being must actually exist, because to suppose otherwise leaves us with the possibility of conceiving something yet greater. Perhaps so, but we may doubt whether such a conceivable being would be greater by virtue of existing rather than not existing, if to exist were not a property contributing at least to an otherwise perfect conceivable being's greatness, as in Descartes and Leibniz. Anselm can answer such questions by maintaining that in his argument existence contributes to the greatest conceivable being's greatness without being a constitutive or identity-determining property inhering in the greatest conceivable being's nature or essence. The conceived-of object is one predication subject, determined by its nature or essence of constitutive identity-determining properties, and its nonsupervenient greatness or otherwise is another matter. Anselm argues that if we conceive of anything that does not exist, then, whatever else we are thinking about, we are not conceiving of the greatest conceivable being. If we are conceiving only of something that is great in many ways, but that does not actually exist, then Anselm holds we are not yet conceiving of the greatest conceivable being or of a being that would be as great as logically possible. The fact that existence contributes to the greatness of a greatest conceivable being by itself does not logically imply that existence is a constitutive or identity-determining property in the nature or essence of a greatest conceivable being. 
Does Anselm's proof, so construed and independently of its merits, fall under Kant's classification of 'ontological arguments'? The question can be approached in at least the following two ways. We can accept tradition and lump Anselm's argument together with what in Kant's sense are the more explicitly ontological arguments of Descartes and Leibniz (the latter of whom merely offers a relatively conservative correction to Descartes'). Or, given the content of Kant's objection, we can allow that Descartes and Leibniz, but not Anselm, offer ontological arguments in the intended sense. They assume in so many words that to exist is a perfection, and that God defined as having all perfections, all and only perfect properties, must therefore exist. We can then inquire as to whether or not Anselm's proof boils down to this same kind of ontological argument. If we follow the first alternative, then, if Anselm's argument is not subject to Kant's criticism, and, in light of the exception, Kant does not refute all ontological arguments. If we opt for the second, then, again, if, as we shall show in either case, Anselm's argument is not subject to Kant's criticism, then Kant's objection may be decisive with respect to all semantic and metaphysically-grounded ontological arguments like Descartes-Leibniz, but they do not refute Anselm's psychological-possibilities-grounded conceivability argument.

Evil is nothing, according to Anselm, and is therefore no part of God's causal or moral responsibility. Does it make sense, consequently, for Anselm to attribute the individuating or identity-determining property, or, speaking anachronistically, Kantian predicate, to evil, in saying that evil is nonexistent or partakes of nonbeing, that it is simply and absolutely nothing? Anselm in effect agrees with Kant across the centuries, maintaining that nonbeing, nonexistence, are not predicates, for it is nothing whatsoever, and as such it is incapable of qualifying any object in any positive way as to any of its properties, not even its categorically most general ontic status as nonexistent. All that is further needed to complete the argument is to observe that if nonbeing or nonexistence is not a Kantian predicate in the required sense, as Kant himself would also agree, then neither is being or existence. If evil were not nothing but a something, in the way that Anselm seems to regard the substantive import of these quantifiers, then, presumably, it could support such alternative ontic categorical properties as being or nonbeing. This is precisely what Anselm denies. We need only compare Anselm's implied difference of attitude toward the Taj Mahal with that of evil as altogether nothing, in order to appreciate the difference. Whereas a full size solid 
glass Taj Mahal does not happen to exist, Anselm, presumably, like Kant, albeit for different reasons, would not attribute nonbeing to a solid glass Taj Mahal as one of its defining attributes. He would not consider there to be a Kantian predicate, object-individuating or identity-determining or identity-constituting property, of being a specifically nonexistent solid glass Taj Mahal. The nonexistent full size solid glass Taj Mahal is solid glass and a mausoleum, and hence a building of a certain sort with certain dimensions, among other things, but for Anselm as for Kant it does not have the property of nonbeing among its defining or characterizing properties. It is true that the object does not exist, so that the nonexistent object can be said to have the ontic property (not a Kantian predicate) of nonbeing, but this ontic property does not contribute toward making it the particular object it is, the (nonexistent) solid glass Taj Mahal. The reason why a full size solid glass Taj Mahal does not exist is instead just that, in fact, as world history has contingently unfolded, no one happens to have made one, nor has one occurred naturally.

We encounter, consequently, a final fundamental question: If Anselm does not assume that God is necessarily identified as a particular object by reference to God's possessing the property of existence, how, then, is Anselm's proof for the existence of God supposed to work? Seeing Anselm's Proslogion in relation to De Casu Diaboli enables us to refine our understanding of Anselm's conceivability argument for the existence of God, and reverse a centuries-old misinterpretation of the argument's intent. If we begin with the assumption, made for purposes of reductio ad absurdum, that God does not exist, then by saying that another being greater than God by virtue of existing rather than not existing would be conceivable, we are not encouraged by anything that Anselm says to suppose that existence is therefore among this entity's Kantian predicates or individuating or identity-determining properties. ${ }^{26}$ Luckily for Anselm, we need make no such assumption about the essential propertyhood of existence in order to understand his reasoning. Indeed, as Kant argues eight hundred years after, it would be mistaken to do so, whether or not precisely this mistake is uncharitably laid at Anselm's door.

All that is required for Anselm's argument to make sense independently of the question of its deductive validity, soundness, and significance, is comprehending what Anselm means by saying that it is not possible to conceive of God as both that than which none greater is conceivable

\footnotetext{
${ }^{26}$ See also Jacquette (1997).
} 
and as not existing. It follows only that Anselm regards existence or being in contrast with nonexistence or nonbeing as contributing to the conceivability of God's greatness, but not necessarily by making God's existence into one of God's individuating or identity-determining properties or Kantian predicates. An existent God is conceivably greater, if Anselm is right, than a nonexistent God. The reason is not because existence is among God's constitutive properties or Kantian predicates, contributing to God's greatness, but simply because as we conceive of the two scenarios, we judge that, if we do, God's existing is something 'greater' than God's not existing. The argument is that we conceive of something greater if we conceive of God as existing than as not existing, although God's identity conditions are logically independent of God's greatness.

This saving feature of Anselm's argument is notably not shared by kindred ontological proofs for the existence of God in Leibniz and Descartes. Descartes in Meditation V argues:

... when we attend to immense power of this being, we shall be unable to think of its existence as possible without also recognizing that it can exist by its own power; and we shall infer from this that this being does really exist and has existed from eternity, since it is quite evident by the natural light that what can exist by its own power always exists. So we shall come to understand that necessary existence is contained in the idea of a supremely perfect being... ${ }^{27}$

Leibniz subsequently offers an important but sympathetic amendment to Descartes' version of the argument, filling in what he perceived as a missing piece of the puzzle in the proof Descartes states, by showing that Descartes' concept of God is logically possible. ${ }^{28}$ The difference between the 'ontological' arguments often mistakenly attributed on Kant's authority to Anselm, on the one hand, and Descartes and Leibniz, on the other, are seen from the standpoint of Kant's objection to this method of proof. We appreciate the impact on both Descartes' and Leibniz's arguments when we consider that what is essential to both is Descartes' conclusion that existence is necessarily contained in the idea of a supremely perfect being, against which Kant's objection is more plainly targeted. Anselm does not talk like this, but speaks instead of what we logically can and cannot conceive concerning the idea of a greatest

${ }^{27}$ Descartes (1984), vol. 2, p. 45. See also Crocker (1976); Beyssade (1992); Kenny (1997); Abbruzzese (2007).

${ }^{28}$ Leibniz (1981), Chapter 10, p. 438. 
conceivable being, a 'supremely perfect being' in Descartes' terminology, which is supposedly to be none other than God.

An existent Anselmian God is not the same thing as a nonexistent Anselmian God. Their ontic properties are manifestly different, just as an existent solid glass Taj Mahal is not the same thing as a nonexistent solid glass Taj Mahal. Anselm's argument does not compel us to conceive of an existent God as constituted in part by the property of existing, thereby precluding the conceivability of a nonexistent God. Anselm's as yet unrefuted conceivability argument equally compels us in another way and for different reasons also to regard a nonexistent God or greatest conceivable being as impossible in the sense of being inconceivable. Existence, in Kant's distinction, is a property of existent things, but it is not a constitutive identity-determining property, not a predicate. Anselm has no need to disagree with any of this, nor does his text encourage dissent from Kant's main point. For Anselm it is the same independently identity-conditioned God that is conceived of as greater if conceived as existing rather than as not existing, from which Anselm concludes that God defined as the greatest conceivable being logically must exist. There is a crucial difference between Anselm's conceivability argument and Leibniz's or Descartes' 'ontological' 'proofs', that Kant's objection neither glosses over nor obscures, but leaves unmentioned as a possible alternative route to the rational demonstration of God's necessary existence. It is a vital distinction that Anselm's discussion of the metaphysics of nonbeing in De Casu Diaboli helps to reinforce, and enables us more clearly to appreciate.

The essential difference between Anselm's conceivability argument and the Kantian 'ontological proofs' of Descartes and Leibniz is that for Anselm existence is not part of God's identity as an entity, on the divine object side of things, but belongs exclusively instead to God's greatness and to the concept of God as that than which none greater is conceivable. ${ }^{29}$

${ }^{29}$ A version of the essay under this title was presented at the International Anselm Conference, University of Kent at Canterbury, England, 22-25 April 2009. I am grateful to Arjo Vanderjagt for insightful comments. 


\section{BIBLIOGRAPHY}

Abbruzzese, John Edward. 2007. 'The Structure of Descartes' Ontological Proof', British Journal for the History of Philosophy, 15: 253-282

Anselm. 1945-1951. Opera omnia, ad fidem codicum recensuit Franciscus Salesius Schmitt. (Edinburgh: Nelson \& Sons), 6 vols.

Anselm. 1967. Anselm of Cantebury: Truth, Freedom, and Evil: Three Philosophical Dialogues, edited and translated by Jasper Hopkins and Herbert Richardson (New York: Harper \& Row, Publishers)

Anselm. 1974. Anselm of Canterbury, translated by Jasper Hopkins and Herbert Richardson (Toronto and New York: Edwin Mellen Press), 4 vols.

Augustine. 2010. Augustinus Opera-Werke (Paderborn: Ferdinand Schöningh)

Bencivenga, Ermanno. 1993. Logic and Other Nonsense: The Case of Anselm and his God (Princeton: Princeton University Press)

Beyssade, Jean-Marie. 1992. 'The Idea of God and Proofs of His Existence', in The Cambridge Companion to Descartes, edited by Willis Doney (Cambridge: Cambridge University Press), pp. 174-199

Brecher, Robert. 1985. Anselm's Argument: The Logic of Divine Existence (Aldershot: Gower Publishing Company)

Crocker, Sylvia Fleming. 1976. 'Descartes' Ontological Argument', The Modern Schoolman, 53: 347-377

Descartes, René. 1984. The Philosophical Writings of Descartes. 3 volumes. Edited and translated by John Cottingham, Robert Stoothoff, Dugald Murdoch, and Anthony Kenny (Cambridge: Cambridge University Press)

Engel, S. Morris. 1963. 'Kant's "Refutation" of the Ontological Argument', Philosophy and Phenomenological Research, 24: 20-35

Henry, Desmond Paul. 1967. The Logic of Saint Anselm (Oxford: The Clarendon Press)

Hume, David. 1947. Dialogues Concerning Natural Religion, edited with an introduction by Norman Kemp Smith (Indianapolis: Bobbs-Merrill)

Jacquette, Dale. 1997. 'Conceivability, Intensionality, and the Logic of Anselm's Modal Argument for the Existence of God', International Journal for Philosophy of Religion, 42: 163-173

Jacquette, Dale. 2010. 'Truth Breakers', Topoi, special issue on 'Logic, Meaning, and Truth-Making States of Affairs in Philosophical Semantics', guest edited by Dale Jacquette, 29: 153-163

Kant, Immanuel. 1965. Critique of Pure Reason (1787), Norman Kemp Smith, trans. (New York: St. Martin's Press)

Kenny, Anthony. 1997. 'Descartes' Ontological Argument', in Descartes' Meditations: Critical Essays, edited by Vere Chappell (New York: Rowman \& Littlefield Publishers, Inc.), pp. 177-194 
Leibniz, G.W. 1981. New Essays on Human Understanding, translated and edited by Peter Remnant and Jonathan Bennett (Cambridge: Cambridge University Press)

Malcolm, Norman. 1960. 'Anselm's Ontological Arguments', The Philosophical Review, 69: 41-62

Plantinga, Alvin. 1966. 'Kant's Objection to the Ontological Argument', The Journal of Philosophy, 63: 537-546

Plantinga, Alvin. 1974. The Nature of Necessity (Oxford: The Clarendon Press)

Schufreider, Gregory. 1978. An Introduction to Anselm's Argument (Philadelphia: Temple University Press)

Shaffer, Jerome. 1962. 'Existence, Predication and the Ontological Argument', Mind, 71: 307-325

Voltaire. 1962. Philosophical Dictionary [Dictionnaire philosophique], translated with an Introduction and Glossary by Peter Gay, Preface by André Maurois (New York: Harcourt, Brace \& World, Inc.)

Voltaire. 1993. Candide, translated and edited (dual language text) by Shane Weller (New York: Dover Publications, Inc.) 